\title{
Thermostatic Radiator Valve Evaluation
}

Jordan Dentz and Eric Ansanelli Advanced Residential Integrated Energy Solutions Collaborative

January 2015 


\section{NOTICE}

This report was prepared as an account of work sponsored by an agency of the United States government. Neither the United States government nor any agency thereof, nor any of their employees, subcontractors, or affiliated partners makes any warranty, express or implied, or assumes any legal liability or responsibility for the accuracy, completeness, or usefulness of any information, apparatus, product, or process disclosed, or represents that its use would not infringe privately owned rights. Reference herein to any specific commercial product, process, or service by trade name, trademark, manufacturer, or otherwise does not necessarily constitute or imply its endorsement, recommendation, or favoring by the United States government or any agency thereof. The views and opinions of authors expressed herein do not necessarily state or reflect those of the United States government or any agency thereof.

Available electronically at http://www.osti.gov/bridge

Available for a processing fee to U.S. Department of Energy and its contractors, in paper, from:

U.S. Department of Energy

Office of Scientific and Technical Information

P.O. Box 62

Oak Ridge, TN 37831-0062

phone: 865.576 .8401

fax: 865.576 .5728

email: mailto:reports@adonis.osti.gov

Available for sale to the public, in paper, from:

U.S. Department of Commerce

National Technical Information Service

5285 Port Royal Road

Springfield, VA 22161

phone: 800.553 .6847

fax: 703.605 .6900

email: orders@ntis.fedworld.gov

online ordering: http://www.ntis.gov/ordering.htm 


\section{Thermostatic Radiator Valve Evaluation}

Prepared for:

The National Renewable Energy Laboratory

On behalf of the U.S. Department of Energy's Building America Program

Office of Energy Efficiency and Renewable Energy

15013 Denver West Parkway

Golden, CO 80401

NREL Contract No. DE-AC36-08GO28308

Prepared by:

Jordan Dentz and Eric Ansanelli

Advanced Residential Integrated Energy Solutions Collaborative

The Levy Partnership, Inc.

1776 Broadway, Suite 2205

New York, NY 10019

NREL Technical Monitor: Stacey Rothgeb

Prepared under Subcontract No. KNDJ-0-40347-05

January 2015 
The work presented in this report does not represent performance of any product relative to regulated minimum efficiency requirements.

The laboratory and/or field sites used for this work are not certified rating test facilities. The conditions and methods under which products were characterized for this work differ from standard rating conditions, as described.

Because the methods and conditions differ, the reported results are not comparable to rated product performance and should only be used to estimate performance under the measured conditions. 


\section{Contents}

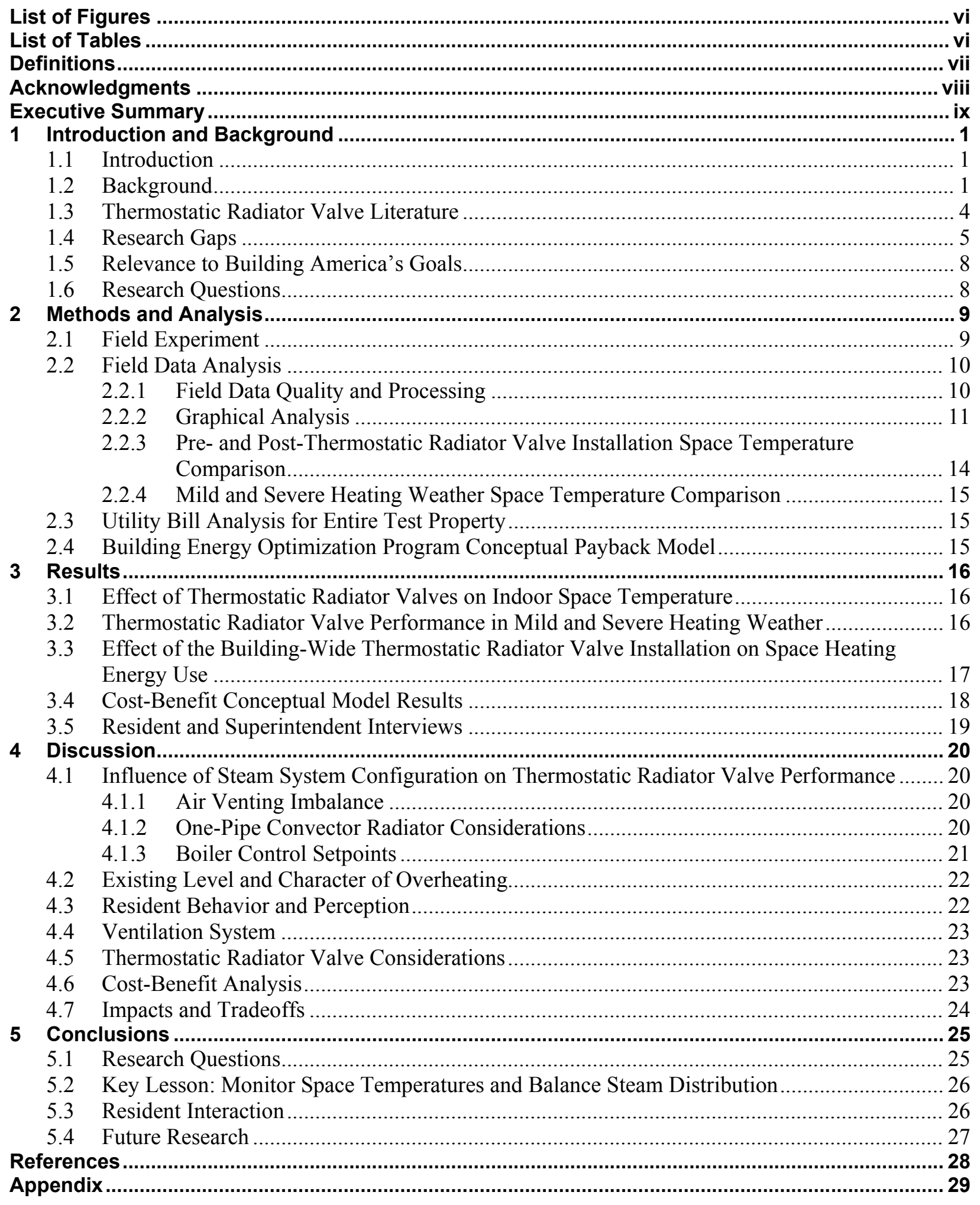




\section{List of Figures}

Figure 1. TRV schematic (Figure courtesy of Danfoss, Inc.) .......................................................... 3

Figure 2. TRV operation (Figure courtesy of Danfoss, Inc.) …...................................................... 4

Figure 3. Typical convector with datalogger, thermocouples, and TRV installed ........................... 10

Figure 4. Typical data from apartment 1F master bedroom .......................................................... 11

Figure 5. Radiator temperatures in apartment $1 \mathrm{~F}$ living room evidencing heating imbalance between pre- and post-TRV installation periods ....................................................................... 12

Figure 6. Radiator temperatures indicating uneven heat distribution between small and master bedrooms in apartment $1 \mathrm{~F}$

Figure 7. Window opening indicated by temperature drops, circled in green, in apartment $1 \mathrm{~F}$ living room (top) and apartment $1 \mathrm{~A}$ living room (bottom)

Figure 8. Heating fuel usage versus average outdoor temperature before and after building-wide TRV installation.

Unless otherwise indicated, all figures were created by the Advanced Residential Integrated Energy Solutions Collaborative.

\section{List of Tables}

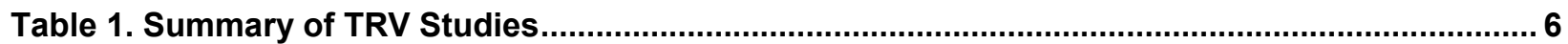

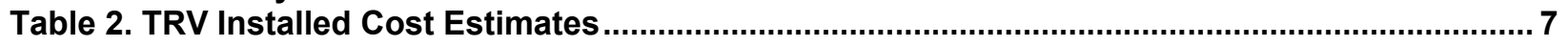

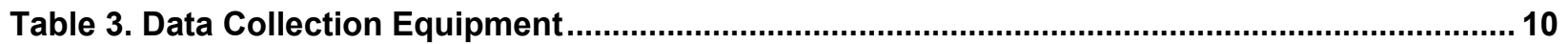

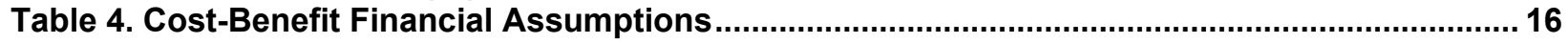

Table 5. Average Pre- and Post-TRV Space Temperatures .......................................................... 16

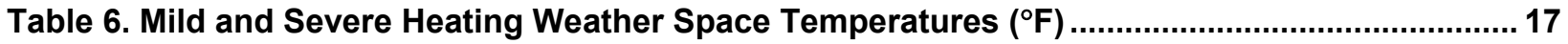

Table 7. Present Value of Fuel Savings Over Life of TRV ......................................................... 18

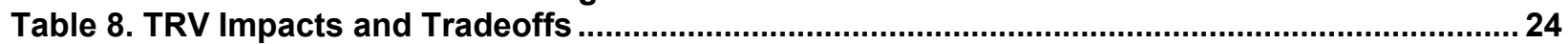

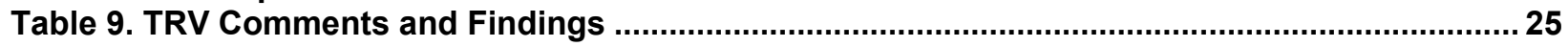

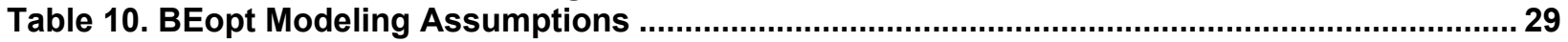

Unless otherwise indicated, all tables were created by the Advanced Residential Integrated Energy Solutions Collaborative. 


\section{Definitions}

BEopt $^{\mathrm{TM}}$

NYSERDA

psi

TRV
Building Energy Optimization Software

New York State Energy Research and Development Authority

Pounds per Square Inch

Thermostatic Radiator Valve 


\section{Acknowledgments}

The authors would like to express their appreciation to Steven Bluestone and Robert Zapisek of the Bluestone Organization for their cooperation in the use of their building as a test bed for this Building America project, and to Bill Boss of Danfoss for technical advice. We are also grateful to Michael Gestwick of the National Renewable Energy Laboratory for guidance and support of this work. 


\section{Executive Summary}

A large stock of multifamily buildings in the Northeast and Midwest uses hot water or steam for space heating. Typically, residents do not pay for heat directly (i.e., heating fuel serves a central plant and use is not submetered). Losses from these systems are typically high, and a significant number of apartments are overheated much of the time. This is often evidenced by open windows on winter days. Controls and distribution are often faulty, and improving them can be more cost effective than replacing boilers.

Thermostatic radiator valves (TRVs), which have been in use for many decades, are one potential strategy to combat this problem. They are commonly used in Europe and in other markets such as commercial buildings, but have not been widely accepted by the residential retrofit market in the northeastern United States. Anecdotal evidence suggests that heating systems engineers and contractors have a variety of opinions about their effectiveness, illustrating a lack of consensus on this potentially important energy efficiency measure. A review of the limited available literature revealed that, in one study, heating fuel savings as high as $15 \%$ was achieved through TRV retrofits.

In this project, the U.S. Department of Energy Building America team, Advanced Residential Integrated Energy Solutions, sought to better understand the current usage of TRVs by key market players in steam and hot water heating and to conduct limited experiments on the effectiveness of new and old TRVs as a means of controlling space temperatures and reducing heating fuel consumption. The project included a survey of industry professionals, a field experiment comparing old and new TRVs, and cost-benefit modeling analysis using BEopt ${ }^{\mathrm{TM}}$ (Building Energy Optimization software). Radiator and apartment space temperature data were collected and analyzed for two similar apartment units in a building that underwent a one-pipe steam TRV retrofit. Space temperature comparisons were made across the pre- and post-TRV installation heating periods and between rooms equipped with old or new TRVs in an attempt to show the comparative effectiveness of each vintage of TRV. Analyses of the heating fuel utility bills before and after the building-wide TRV installation were conducted to quantify potential savings.

The results of the field experiment and utility bill analysis did not show energy savings at either the unit or the building-wide level. The results provided inconclusive answers to the original study questions but provided valuable insight into common steam system imbalance and resident behavior issues that are critical to address in conjunction with TRV retrofits. Specific issues identified included steam distribution imbalance, possible TRV sensor location issues, a persistent window-opening habit, and a failure to optimize the boiler control set points as part of the TRV retrofit. The lack of heating fuel savings underscored the need to include whole steam system commissioning alongside or as a prerequisite to TRVs. Failed air vents and uneven steam main venting are critical to address either in conjunction with or before a TRV installation. Monitoring existing space temperatures before a retrofit strategy is chosen would allow the consultant and building owner to better assess the potential benefits of a whole-building TRV retrofit, selective installation of TRVs in some units, or simply balancing the steam distribution venting. 
Further gaps in the understanding of underlying processes that allow TRVs to function effectively were also identified and are presented as opportunities for future research. 


\section{Introduction and Background}

\subsection{Introduction}

A large stock of multifamily buildings in the Northeast and Midwest uses hot water or steam for space heating. Typically, residents do not pay for heat directly (i.e., heating-related energy use is not submetered). Losses from these systems are typically high because a significant number of apartments are overheated much of the time. This is often evidenced by open windows on cold winter days. Controls and distribution are often faulty, and improving them can be more cost effective than replacing boilers.

Thermostatic radiator valves (TRVs), which have been in use for many decades, are one strategy to combat this problem. They are commonly used in Europe and in other markets such as commercial buildings, but have not been widely accepted by the residential retrofit market in the northeastern United States. The following observations were made at the Hydronic Heating Systems Expert Meeting (ARIES Collaborative, 2011), and illustrate a divergence of opinions about and experience with TRVs, including that TRVs are limited by their durability, that they can be effective if used correctly, and that psychological factors increase tenant comfort without significantly affecting space temperatures.

Other anecdotal evidence, including that collected over the course of this research study, suggests that heating systems engineers and contractors have a variety of opinions on the effectiveness of TRVs, illustrating a lack of consensus on this potentially important energy measure.

\subsection{Background}

Central hydronic and steam space heating systems typically work by generating heat in a central location (the boiler or boilers) and transmitting that heat to the various parts of the building through pipes carrying hot water or steam. Often, multifamily buildings with these systems have one or a few heating zones with no or very limited ability to control the heat locally. There are three main types of such space heating distribution systems in the United States:

- One-pipe steam systems. In these systems, steam is generated in a boiler and then transmitted to different parts of the building through a network of pipes that gradually diminish in size as they become more distant from the boiler. The steam then enters radiators in the spaces, gives up the heat, condenses into the bottom of the radiator, then drains down to the boiler through the same pipes that it came up in. Venting of steam lines is critical in one-pipe steam systems; only with properly sized and operating air vents on headers, risers, and radiators will steam reach all radiators at approximately the same time, which is a hallmark of a well-tuned system. One-pipe steam systems are commonly found in older buildings, especially those built before 1970 .

- Two-pipe steam systems. In these heating systems, steam is transmitted through one pipe and the condensate (water) returns to the boiler through a second pipe connected to the back end of the heat emitter (radiator). Two-pipe systems rely on steam traps to prevent steam from passing through the radiator and exiting into the condensate return pipe. Both one-pipe and two-pipe steam systems are typically controlled by warm weather shut-off controls in which the boiler stops supplying heat to the building if the 
outdoor air temperature reaches a predetermined threshold. Outdoor reset controls cycle the steam supply as a function of outdoor temperature to deliver only the heat required given the current weather. Two-pipe steam systems are common in larger buildings built after 1970.

- Hot water systems. Hot water systems are also common in multifamily buildings. Boilers provide hot water to the radiators or other heat emitters and the return water is pumped back to the boiler to be reheated. Often, multifamily hot water systems have circuit setters or balancing valves to make one-time or periodic adjustments to balance the heat distribution. Hot water systems are also two-pipe systems. Most multifamily hot water boilers are controlled by outdoor reset control where the supply water temperature is controlled as a function of outdoor temperature.

Steam and hot water heating systems in multifamily buildings can overheat buildings. While there is no single definition of overheating, studies point to temperatures above the range of $70^{\circ}-$ $72^{\circ} \mathrm{F}$ (Dentz, Henderson, \& Varshney, 2013) (McNamara, 1995). Overheating is recognized as a problem (Urban Green Council, 2012) and proven out by data. In a recent project by the U.S. Department of Energy Building America team, Advanced Residential Integrated Energy Solutions (Dentz, Henderson, \& Varshney, 2013), 18 multifamily residential buildings were investigated to quantify overheating. The data were obtained from the archives of companies that provide energy management systems to multifamily buildings. Energy management systems typically include temperature sensors in apartments networked to a central controller that modulates the heating system. This study concluded that all the buildings were overheating at some point during the heating season. In 15 of the 18 buildings, average temperatures in all the apartments exceeded $70^{\circ} \mathrm{F}$ (ranging from $70.7^{\circ} \mathrm{F}$ to $87.4^{\circ} \mathrm{F}$ ). In the remaining three buildings, average temperatures in $88 \%$ of apartments exceeded $70^{\circ} \mathrm{F}$ (ranging from $70.3^{\circ} \mathrm{F}$ to $85.2^{\circ} \mathrm{F}$ ).

Efficient control of heating systems has a large influence on energy savings and on the thermal comfort of residents. According to the U.S. Department of Energy, overheating can increase annual heating fuel usage by as much as 3\% for each degree Fahrenheit above the desired space temperature set point (U.S. Department of Energy, 2013).

Building overheating can vary in general severity, in spatial distribution, and temporally. Generally, the building-wide, heating-season average space temperature can be some number of degrees Fahrenheit above the desired set point or the legally mandated minimum (this varies by municipality; e.g., $68^{\circ} \mathrm{F}$ during daytime heating season hours in New York City) (New York City Administrative Code \$27-2029). Space temperatures can vary from apartment to apartment depending on the performance of the distribution system and the building envelope; space temperatures can also vary across time because of heating system cycles, programmed setbacks, end-user (building superintendent and/or occupants) manipulation, and weather severity. This variation affects the strategy chosen to remedy overheating issues. If overheating is consistent throughout a building and across time, reducing heat at the central heating plant is a logical solution. However, if the space temperature varies widely between apartments and over time, the solution may involve heating plant control and distribution system measures.

Depending on the system type, there are a number of ways to balance the system and even out distribution, after which the central heat supply can be reduced. For one-pipe steam, venting is a 
primary means (McNamara, 1995) (Jayne Choi, 2012). Two-pipe systems can often benefit from properly sized orifices and correcting faulty steam traps (Gifford, 2003). For hot water systems, adjusting the balancing valves can help (Trüschel, 2002). However, for many buildings this may not be sufficient, meaning that local controls will be required. One room-level strategy is using a local powered two-way zone valve and thermostat. This strategy provides a high level of control but requires low voltage power to the valve and is expensive (at least $\$ 350$ per unit). TRVs are a potentially lower cost room-level strategy, particularly for certain applications.

TRVs do not require electric power. They consist of a valve and an operator as shown in Figure 1. A fluid-filled capsule inside the TRV operator expands as room temperature increases. As it expands, it closes the valve. In the case of one-pipe steam, the TRV is connected to the air vent and blocks the release of air when it is in the closed position, preventing steam from entering the radiator (Figure 2). When the room temperature decreases, the capsule contracts; this allows air to escape the radiator and steam to take its place. In the case of two-pipe steam, the TRV is connected to the radiator inlet and, when in the closed position, prevents steam from entering the radiator body entirely.

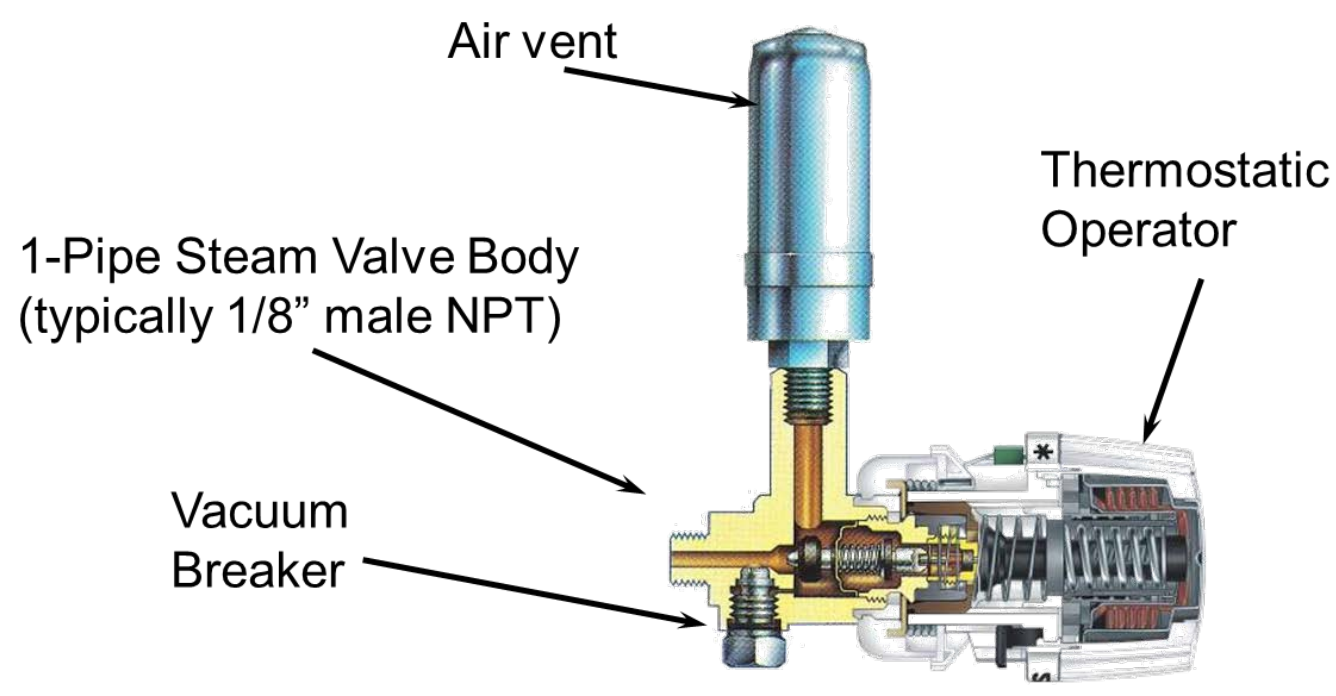

Figure 1. TRV schematic (Figure courtesy of Danfoss, Inc.) 


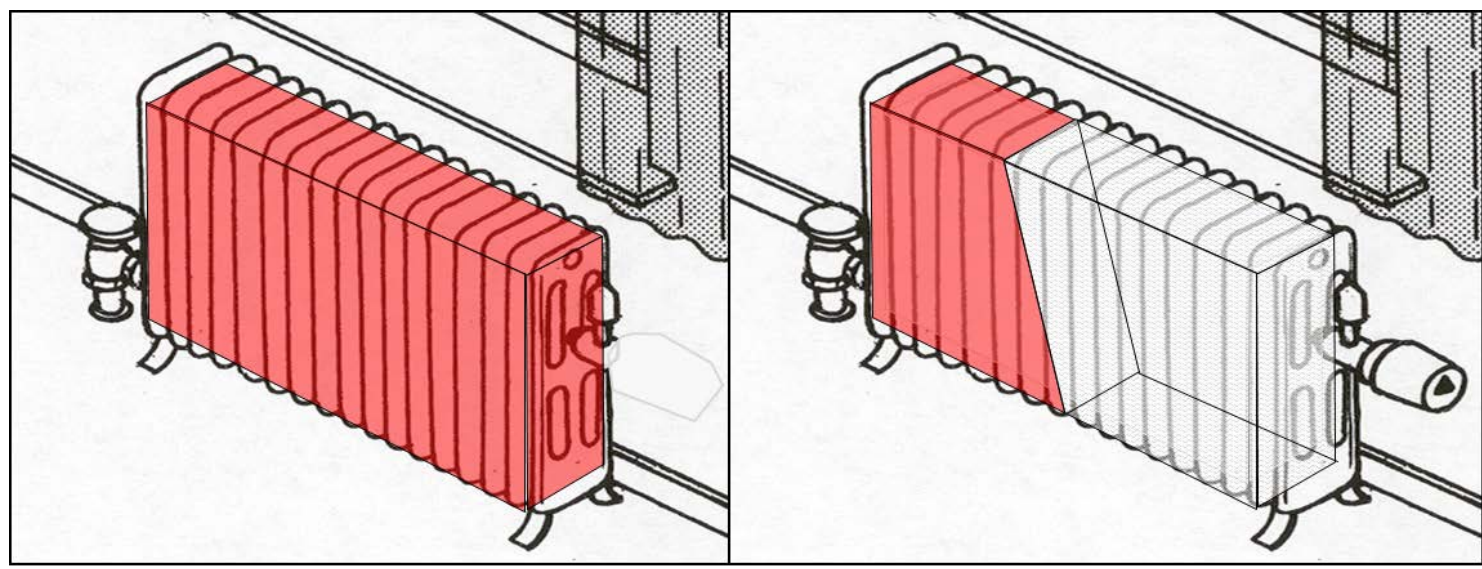

Air Vent Only

1. Steam enters the radiator and forces air out through the vent

2. Steam reaches air vent; vent closes

3. Radiator, filled with steam, radiates heat into room

4. Overheating can occur
With TRV

1. Steam enters the radiator and forces air out through the vent

2. When room reaches target temperature, TRV closes, preventing air from escaping and more steam from entering

Figure 2. TRV operation (Figure courtesy of Danfoss, Inc.)

As the room temperature decreases, the capsule contracts, opening the TRV and allowing steam to enter the radiator. A knob on the operator allows an occupant to adjust the temperature at which heat is allowed into the heat emitter (Gifford, 2004). The small body of published literature on TRV performance is summarized below.

\subsection{Thermostatic Radiator Valve Literature}

Several studies on TRV performance conclude that they work well and can be used to control space temperatures (Peterson, 1985) (Trüschel, 2002). Peterson (1985) found that rebalancing a steam system can save as much as $15 \%-25 \%$ heating fuel and that TRVs can be used to reduce overheating in a zone. Trüschel (2002) ran simulations and conducted a field study on hydronic (hot water) heat systems and found that TRVs are most effective in low-flow systems, partly because of increased radiator sensitivity to flow changes.

In a project funded by The New York State Energy Research and Development Authority (NYSERDA), Michael McNamara (1995) evaluated the effectiveness of TRVs in eliminating overheating in apartments and in saving energy. A total of 224 TRVs were installed and monitored for energy consumption for 3 years (1991-1994) in eight privately owned multifamily buildings. All the buildings had one-pipe, low-pressure steam distribution systems. As a prerequisite to project participation, steam main and radiator air vents were inspected before the baseline data were collected. TRVs were installed with set points of $72^{\circ} \mathrm{F}$ in half the apartments in four buildings. The buildings with partial installations reduced their annual heating use an average of $9 \%$. After full installation, the average annual heating use savings totaled $15 \%$. Payback ranged from 1 to 5 years in those buildings where TRVs produced energy savings. The 
study recommended installing TRVs on one-pipe steam distribution systems in apartments that are heated higher than $72^{\circ} \mathrm{F}$, those where the control system causes temperatures to fluctuate higher than $72^{\circ} \mathrm{F}$, and in specific rooms in which the radiator has become oversized because thermal-pane windows were installed.

Tahersima et al. (2010) derived a model for a heating, ventilation, and air-conditioning system consisting of a room and a hydronic radiator with a TRV with a step motor to adjust the valve opening. The modeling presented in the article sheds light on a regular and undesirable phenomenon that occurs in low-demand situations: when flow is very low in the radiator and the supply water temperature and the pressure drop across the valve are constant, room temperature frequently oscillates. The simulations show that the oscillations occur partly because of the high gain of the radiator in low-demand weather conditions and the subsequent low flows.

In another simulation study, Tahersima et al. (2011) derived a linear parameter-varying model of a radiator that was based on the operating flow rate, room temperature, and radiator specifications. They presented a solution to the partial differential equation of a radiator's heat transfer dynamics. The simulations showed that the designed controller based on the proposed model performs well and is stable under full operating conditions.

Weker and Mineur (1980) presented a performance index for TRVs derived from standard equations that define the heating process in a system. The effect of outside temperature on room temperature is slight if controlled by a TRV with a high performance index. Their analysis shows how to optimize a TRV design for any sensor and actuator and for a given temperature control band. The analysis provides insight into the effects of water flow and temperature changes on pre-retrofit room temperature. This study also provides a theoretical and practical basis for comparing the energy-saving performance of TRVs on hot water systems.

$\mathrm{Xu}$ et al. (2008) developed a model for simulating the thermal and hydraulic behavior of space heating systems with radiators controlled by TRVs in multifamily buildings. The authors developed submodels for rooms, radiators, and TRVs and then integrated the submodels to obtain a full model for the building that takes into account heat transfer across walls and the selfadjusting characteristic of TRVs. They further tested the model by investigating two space heating systems in multifamily buildings and found a good agreement between measured and simulated values. The study showed that an approximate $12.4 \%$ reduction of heat consumption could be expected with TRVs.

\subsection{Research Gaps}

Despite being an old technology, the published literature on TRVs is limited; eight published studies were identified (Table 1). Four were purely modeling and four were published field evaluations.

Based on the literature and interviews, it is unclear how effective TRVs remain after many years in service. A number of interviewees believed that TRV performance deteriorates with time. No study was found to confirm or dispute this opinion. 
Table 1. Summary of TRV Studies

\begin{tabular}{|c|c|c|c|c|}
\hline Study & Type & Application & $\begin{array}{l}\text { Type of } \\
\text { System }\end{array}$ & Finding \\
\hline $\begin{array}{l}\text { (McNamara, } \\
\text { 1995) }\end{array}$ & Experimental & $\begin{array}{l}\text { Eliminating } \\
\text { overheating in } \\
\text { multifamily } \\
\text { buildings }\end{array}$ & $\begin{array}{l}\text { One-pipe } \\
\text { steam }\end{array}$ & $\begin{array}{l}\text { TRVs saved approximately } 15 \% \\
\text { heating energy and payback was } \\
\text { shorter than } 5 \text { years. }\end{array}$ \\
\hline $\begin{array}{l}(\mathrm{Xu}, \mathrm{Fu}, \boldsymbol{\&} \\
\text { Di, 2008) }\end{array}$ & Modeling & $\begin{array}{l}\text { Heating energy } \\
\text { savings }\end{array}$ & $\begin{array}{l}\text { Hydronic } \\
\text { heating }\end{array}$ & $\begin{array}{l}\text { If the set value of the TRVs were } \\
\text { kept on } 2-3 \text {, about } 12.4 \% \\
\text { reduction of heat consumption } \\
\text { could be expected. When an } \\
\text { apartment stopped using the } \\
\text { heating system during a heating } \\
\text { season, the heat consumption of its } \\
\text { neighboring apartments would } \\
\text { increase by about } 6 \%-14 \% \text {. }\end{array}$ \\
\hline $\begin{array}{l}\text { (Weker \& } \\
\text { Mineur, } \\
\text { 1980) }\end{array}$ & $\begin{array}{l}\text { Theoretical } \\
\text { and } \\
\text { experimental }\end{array}$ & $\begin{array}{c}\text { Optimize the } \\
\text { design of a TRV }\end{array}$ & $\begin{array}{l}\text { Hydronic } \\
\text { heating }\end{array}$ & $\begin{array}{c}\text { Presented performance index for } \\
\text { TRVs. }\end{array}$ \\
\hline $\begin{array}{l}\text { (Tahersima } \\
\text { et al. 2011) } \\
\text { and } \\
\text { (Tahersima } \\
\text { et al. 2010) }\end{array}$ & Modeling & $\begin{array}{c}\text { Stabilize } \\
\text { oscillatory } \\
\text { behavior of TRVs } \\
\text { under low heat } \\
\text { demands }\end{array}$ & $\begin{array}{l}\text { Hydronic } \\
\text { heating }\end{array}$ & $\begin{array}{l}\text { A TRV controller is presented that } \\
\text { keeps it stable over the range of } \\
\text { operating conditions. }\end{array}$ \\
\hline $\begin{array}{l}\text { (Peterson, } \\
\text { 1985) }\end{array}$ & Experimental & $\begin{array}{l}\text { Reducing } \\
\text { overheating }\end{array}$ & $\begin{array}{l}\text { One-pipe } \\
\text { steam }\end{array}$ & $\begin{array}{l}\text { Rebalancing a steam system can } \\
\text { save as much as } 15 \%-25 \% \text { heating } \\
\text { fuel. TRVs can be used to reduce } \\
\text { overheating in a zone. }\end{array}$ \\
\hline $\begin{array}{l}\text { (Trüschel, } \\
\text { 2002) }\end{array}$ & $\begin{array}{l}\text { Modeling } \\
\text { and field } \\
\text { work }\end{array}$ & $\begin{array}{l}\text { Reducing } \\
\text { overheating }\end{array}$ & $\begin{array}{l}\text { Hydronic } \\
\text { heating }\end{array}$ & $\begin{array}{l}\text { TRVs are most effective in low- } \\
\text { flow systems because the radiators } \\
\text { are sensitive to flow changes. }\end{array}$ \\
\hline
\end{tabular}

A brief search was conducted of state and utility energy efficiency programs. Only one utility program, from Consolidated Edison of New York, was found to offer rebates for TRVs. To the authors' knowledge, only one state program, NYSERDA's Multifamily Performance Program, encourages TRVs. According to NYSERDA, TRVs are used modestly in the program, being recommended (but not necessarily used) for about 10\% of apartments, about 17,000 apartments since 2007 (Colgrove, 2012). Most buildings in the Multifamily Performance Program have steam or hot water heating. The Consolidated Edison program started off slowly but gained momentum, and in its second year installed 11,000 TRVs in 176 (mostly one-pipe steam) buildings. Consolidated Edison offered a rebate of $\$ 115$ per TRV (Madnick, 2014). Interestingly, approximately two-thirds of these installations were installed by a single contractor. 
In conversations with engineers and contractors, it became apparent that, even among experienced professionals, there is a range of understanding and opinions regarding the effectiveness and applicability of TRVs. Nearly all consultants and contractors agreed that TRVs are effective heat-limiting devices in some applications; however, a number doubted that they worked for one-pipe steam systems. Some consultants had little experience or knowledge of TRVs and expressed a desire for more information. The dominant view among those with experience was that, because of their relatively high installed cost, TRVs are best used selectively in spaces that are reported to be overheated. Most agreed that other means of improving heat delivery, such as balancing, installing orifices for two-pipe steam, and using boiler controls should be the first strategies, be followed by TRVs where needed.

The perception of costs ranged widely (see Table 2). The consultants felt that TRVs were too expensive, even though their cost estimates were typically lower than actual supplier and contractor costs.

Table 2. TRV Installed Cost Estimates

\begin{tabular}{c|c|c|c|c}
\hline Application & Low & High & Median & $\begin{array}{c}\text { Actual } \\
\text { (based on supplier and contractor prices) }\end{array}$ \\
\hline One-Pipe Steam & $\$ 65$ & $\$ 300$ & $\$ 140$ & $\$ 110$ do-it-yourself; $\$ 160-\$ 225$ contractor \\
\hline Two-Pipe Steam & $\$ 65$ & $\$ 315$ & $\$ 140$ & $\$ 240-\$ 315$ \\
\hline Hot Water & $\$ 87.5$ & $\$ 315$ & $\$ 213$ & $\$ 250-\$ 315$ (not including cost of draining) \\
\hline
\end{tabular}

There was a general consensus that TRVs are rarely seen on multifamily audits; that they are underutilized, and have a large untapped potential. Most interviewees also recognized that while TRVs are generally simple to install, there are numerous ways to install them incorrectly that can lead to subpar performance, and incorrect installation is commonplace. Mistakes include poorly positioned valves and sensors and a failure to ensure that the overall system is working with the TRVs (i.e., system pressure and cycle lengths are appropriate). Most agree that TRVs are very reliable and durable. However, some have concerns stemming from specific experiences such as failures attributed to failed seals (hypothesized to be due to repeated wetting and drying in steam systems) and others due to hypothetical concerns such as particulates fouling the valves or imprecise air temperature sensing.

Few respondents were familiar with range-limited TRVs, which might address concerns related to improper usage by tenants (i.e., turning the knob to maximum and continuing to open windows). Tenant misuse was a common theme, with anecdotal reports of vandalism or opening of windows; however, admittedly few or no data were available on this phenomenon prior to this study.

Of 12 consultants actively working on building heating systems, seven sometimes recommend TRVs and five do not or do so rarely. Five of the 16 non-manufacturer/supplier interviewees did not think TRVs would be effective on one-pipe steam systems. Two consultants volunteered the 
opinion that more data are needed on the interaction between TRVs and various boiler control systems.

\subsection{Relevance to Building America's Goals}

This project addresses the following Building America Implementation Standing Technical Committee milestone:

"Deliver systems and strategies that achieve 10\%-15\% space conditioning energy savings by upgrading existing heating/cooling equipment for homes where [heating, ventilation, and air conditioning] HVAC change-out is not cost effective" (National Renewable Energy Laboratory, 2012).

This project evaluates the cost and effectiveness of a technology that can improve the efficiency of existing steam and hot water heating systems. The literature indicates that up to $15 \%$ heating energy savings are possible (McNamara, 1995).

\subsection{Research Questions}

This research addresses the following questions:

1. What are common prevailing opinions and perceptions regarding TRVs in the building community and how does this affect their deployment?

2. How effective are new and old TRVs in controlling indoor temperature under various outdoor conditions?

3. How much space heating energy can be saved through TRV installations and how cost effective are TRV retrofits in low-rise multifamily buildings? 


\section{Methods and Analysis}

The project consisted of the following components:

- Literature review of TRV research

- Evaluation of the market perception of TRVs through discussions with leading heating system engineers and contractors

- Monitoring indoor air and radiator temperatures in two apartments before and after TRVs were installed (one apartment received new TRVs and the other received TRVs that were at least 10 years old)

- Estimated energy savings via modeling based on the change in indoor air temperatures in the apartments after the TRVs were installed and actual savings based on utility bills from the test building (all other apartments in the building received new TRVs during the summer of 2013).

\subsection{Field Experiment}

Data loggers were installed in a multifamily building in Flushing, New York, to monitor space and heat emitter temperatures in each room of two apartments (kitchen, bedroom, master bedroom, and living room). These apartments were located on the floor above the boiler room and had identical floor plans, with equal areas of exterior wall/glazing. The contractor who installed the TRVs throughout the rest of the building placed the TRV sensor components for each radiator outside the convector cabinet, several inches away on the exterior wall. This was not the manufacturer's preferred location; the sensors should be positioned below the convector and inside the convector cabinet to be protected from unintended impacts and wear. The sensors in the two test apartments, however, were installed in the suggested location. The existing radiator air vents were not replaced with new vents at the time of the TRV installation.

The building has a one-pipe steam system with convectors. The natural gas-fired (with interruptible oil service) boiler (Weil McLain model H1388S) is controlled with a Heat Timer MPC outdoor reset boiler controller. The existing control settings (reset curve "I" for both day and night throughout the heating season; boiler operating pressuretrol set to operate at 2-5 psi) remained unchanged after the building-wide TRV installation was completed in the summer of 2013. The TRV manufacturer recommended steam pressure no greater than 2 psi be used in conjunction with the TRVs.

The following measurements were collected during the 2013-2014 winter season:

- Surface temperature of each radiator with T-type surface mounted thermocouples mounted at three locations on each radiator (inlet, midpoint, and vent end)

- Indoor space temperatures in each of the four rooms in each apartment (consistent with the Building America indoor temperature measurement protocol (Metzger \& Norton, 2014))

- One T-type thermocouple near the window above each radiator, to determine if the window is opened. 
The following equipment (Table 3) was used to perform the measurements described above.

Table 3. Data Collection Equipment

\begin{tabular}{c|c|c}
\hline Measurement & Equipment & Frequency \\
\hline Radiator Surface Temperatures & U-12 datalogger with T-type thermocouples & $1 \mathrm{~min}$ \\
\hline Near-Window Temperature & U-12 datalogger with T-type thermocouples & $1 \mathrm{~min}$ \\
\hline Indoor Air Temperature & UX100-001 datalogger & $5 \mathrm{~min}$ \\
\hline
\end{tabular}

The sensors were installed on October 8, 2013, before the start of the heating season. Data were collected throughout the first half of the winter. TRVs were installed in the two test apartments in January 13, 2014, and data collection continued through the end of the heating season.

In the case of the older, previously used TRVs (apartment 1F), the valve bodies and seats had seen approximately 10 years of service in a prior installation. The operators installed with them had not been previously used but were also at least 10 years old and had experienced normal space temperature fluctuations while in storage. As the two likely points of failure are the valve seats (which may lose their tight seal) and the bellows elements (which are subject to frequent expansion and contraction), heavily used TRVs in one of the two monitored apartments were installed to determine whether the older equipment had suffered any loss of performance.

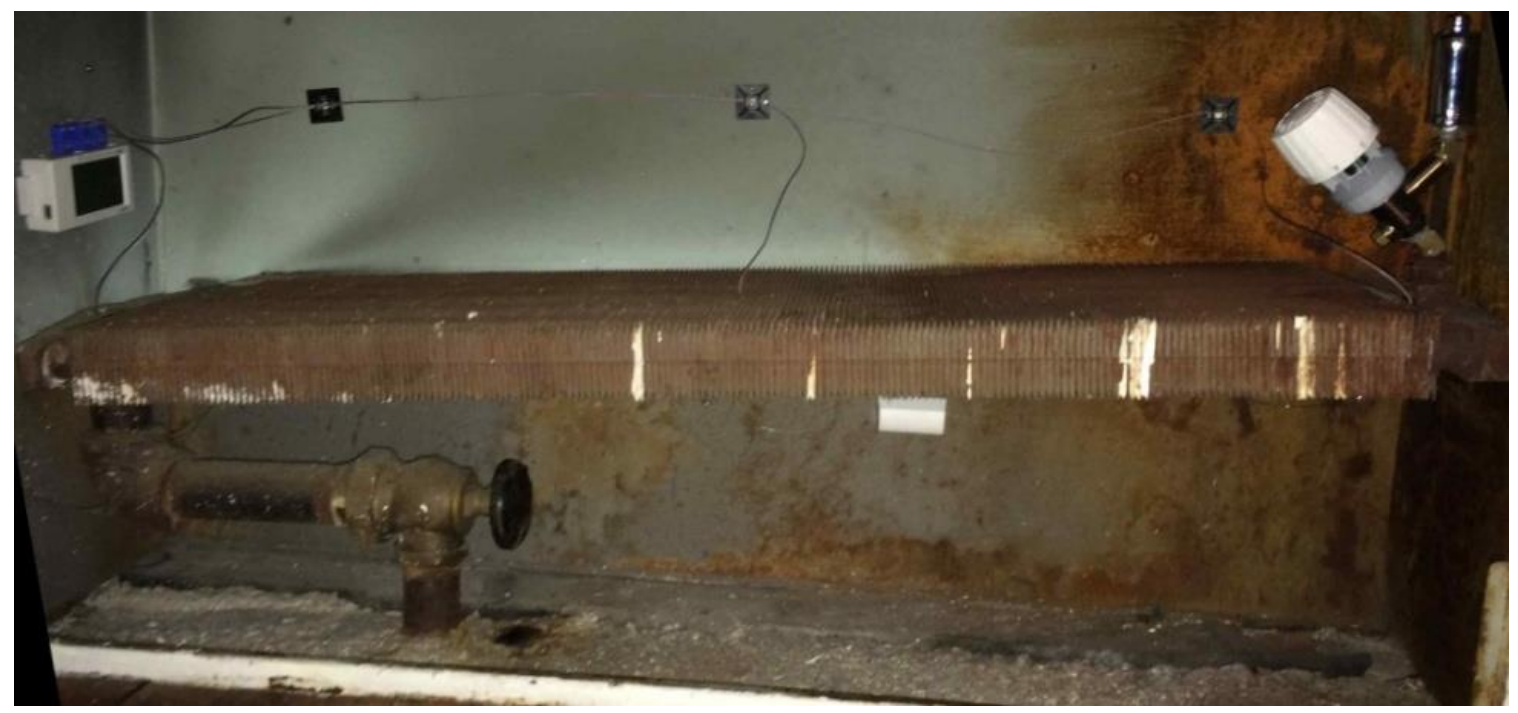

Figure 3. Typical convector with datalogger, thermocouples, and TRV installed

\subsection{Field Data Analysis}

\subsubsection{Field Data Quality and Processing}

Hour-interval outdoor temperature records from the nearby LaGuardia airport weather station were interpolated against the space temperature, radiator, and near-window temperature readings obtained from the test site. Some temperature readings, especially those taken from the radiator 
points, began to degrade over the course of the collection period. The frequent and extreme fluctuations in the temperature of the radiator surface may have caused the thermocouples to malfunction. Radiator temperatures lower than $30^{\circ} \mathrm{F}$ and higher than $220^{\circ} \mathrm{F}$ were deemed inaccurate and removed from consideration, as were any near-window temperatures recorded as lower than $0^{\circ} \mathrm{F}$ or higher than $100^{\circ} \mathrm{F}$. Space temperatures were recorded on separate sensors and did not show any errant readings.

\subsubsection{Graphical Analysis}

Individual data sets for each of the eight rooms in apartments $1 \mathrm{~F}$ and $1 \mathrm{~A}$ were graphed alongside outdoor temperature and analyzed visually. This revealed some of the data quality issues mentioned above as well as several aspects of heating system operation and resident behavior.

The sample graph below (Figure 4) shows typical temperature data from all six sensor channels over a 2-day period in January 2013 for the master bedroom in apartment 1F:

- The blue line at the bottom is outdoor temperature. The bottom of the trough on the righthand side is a result of the early January "polar vortex."

- Space temperature hovers at $65^{\circ}-75^{\circ} \mathrm{F}$ for this time period.

- The blue, red, and green lines indicate the temperatures of the radiator inlet, midpoint, and valve end, respectively. The inlet is cooler than the midpoint, likely because cooler condensate drains back through the inlet.

- From left to right, the figure shows that the boiler does not run during the relatively mild night of January 6 , indicating that the boiler control nighttime setback feature is working. Regular hourly cycles occur over the course of both days, and the longer boiler cycle in the middle of the graph reflects the "morning boost" feature of the boiler control.

- Longer boiler cycles are observable during the colder day of January 7.

- The abrupt drops in near-window temperature (purple line) indicate window opening events.

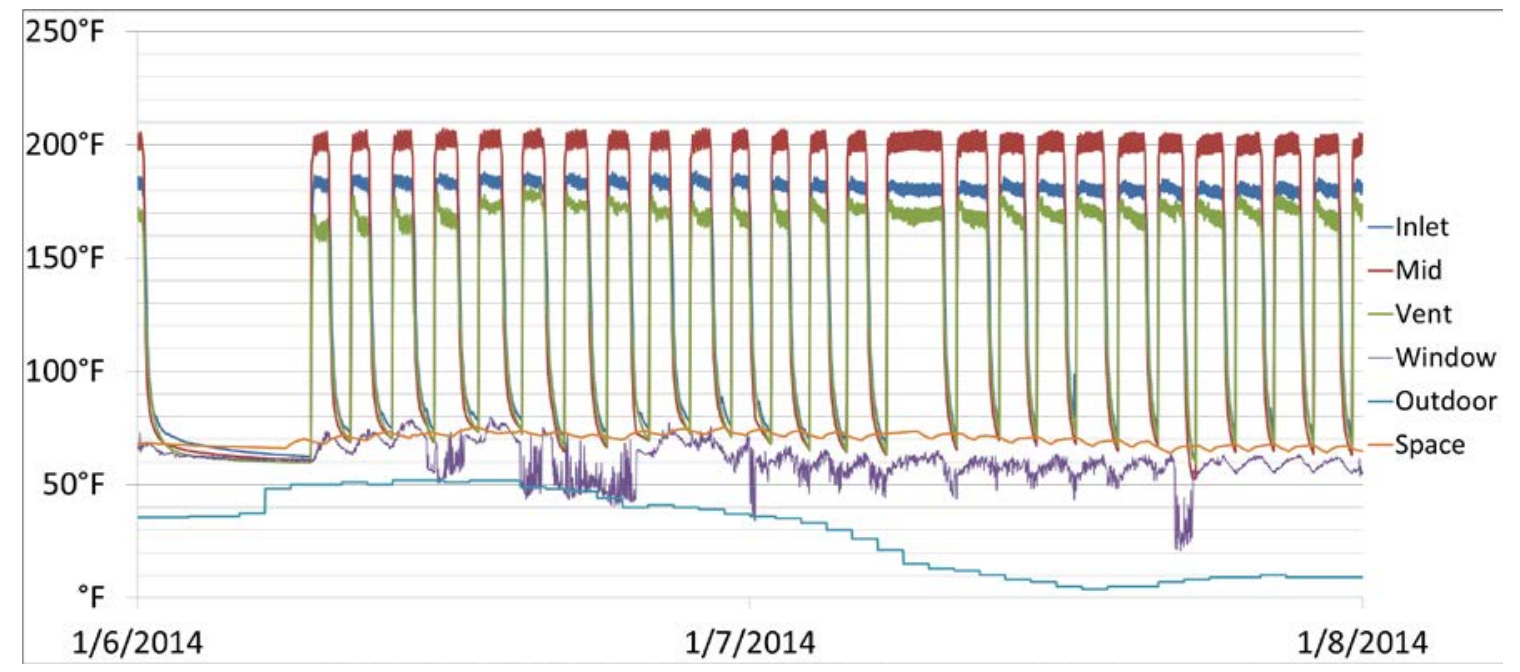

Figure 4. Typical data from apartment 1F master bedroom 
Several graphs indicate an imbalance in steam distribution. Figure 5 shows that the living room radiator in apartment $1 \mathrm{~F}$ was not filling with steam until after the TRV installation date of January 13. This trend held consistently for the entire pre- and post-TRV installation periods for that room. The cause may have been that the inlet valve was in the closed position, but more likely the air vent had an unintended obstruction that was alleviated when the new vent was installed as part of the TRV installation.

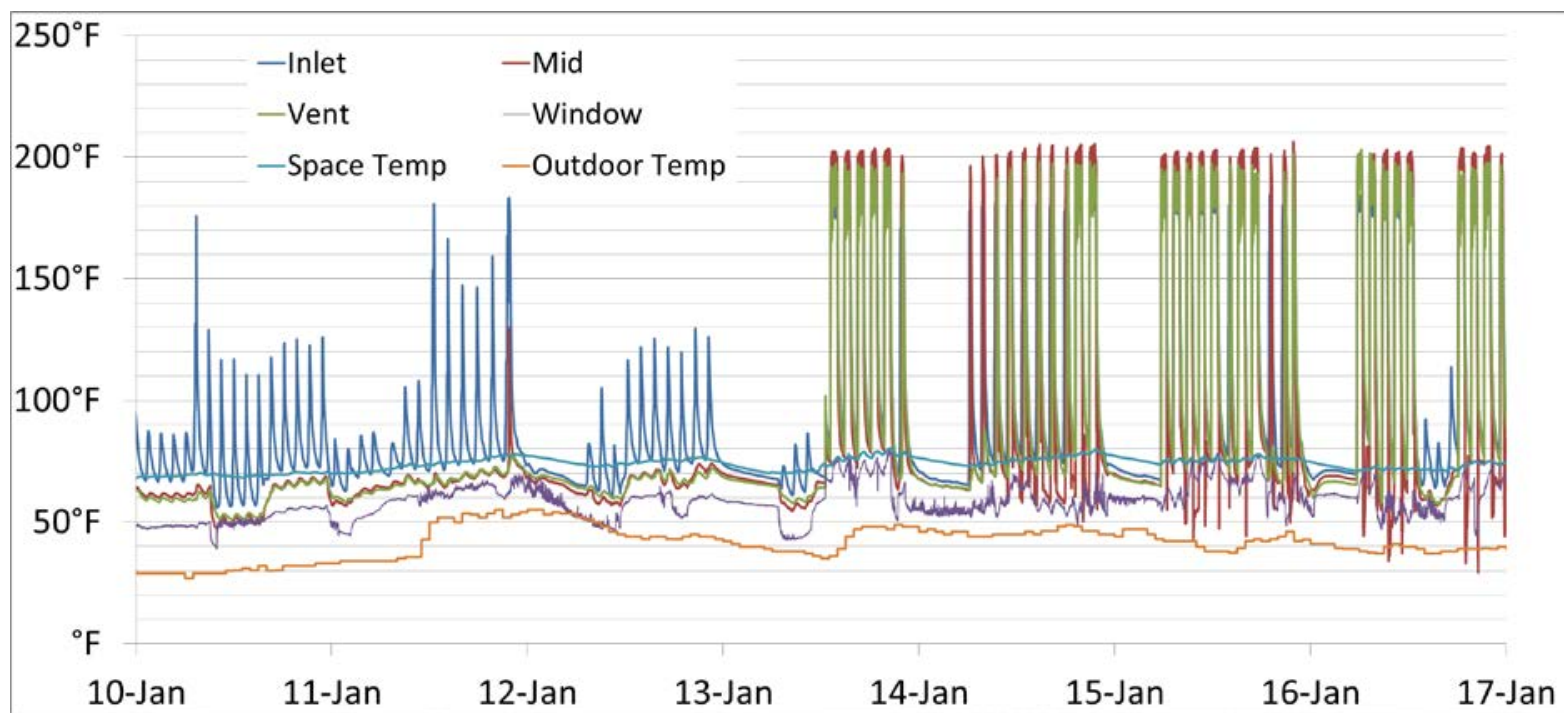

Figure 5. Radiator temperatures in apartment 1F living room evidencing heating imbalance between pre- and post-TRV installation periods

Figure 6 overlays temperature data from the small and master bedrooms in apartment 1F for a 3day period that occurred post-TRV installation. The midpoint temperature of the small bedroom radiator (shown in pink) never exceeds $150^{\circ} \mathrm{F}$, even though the master bedroom radiator temperature (shown in dark red) shows that the boiler is operating. This cannot be attributed to the function of the TRV in the small bedroom because its space temperature (indicated by the bright red line) remains mostly in the low $60^{\circ} \mathrm{F}$ range at the times when the radiator is not getting heat. 


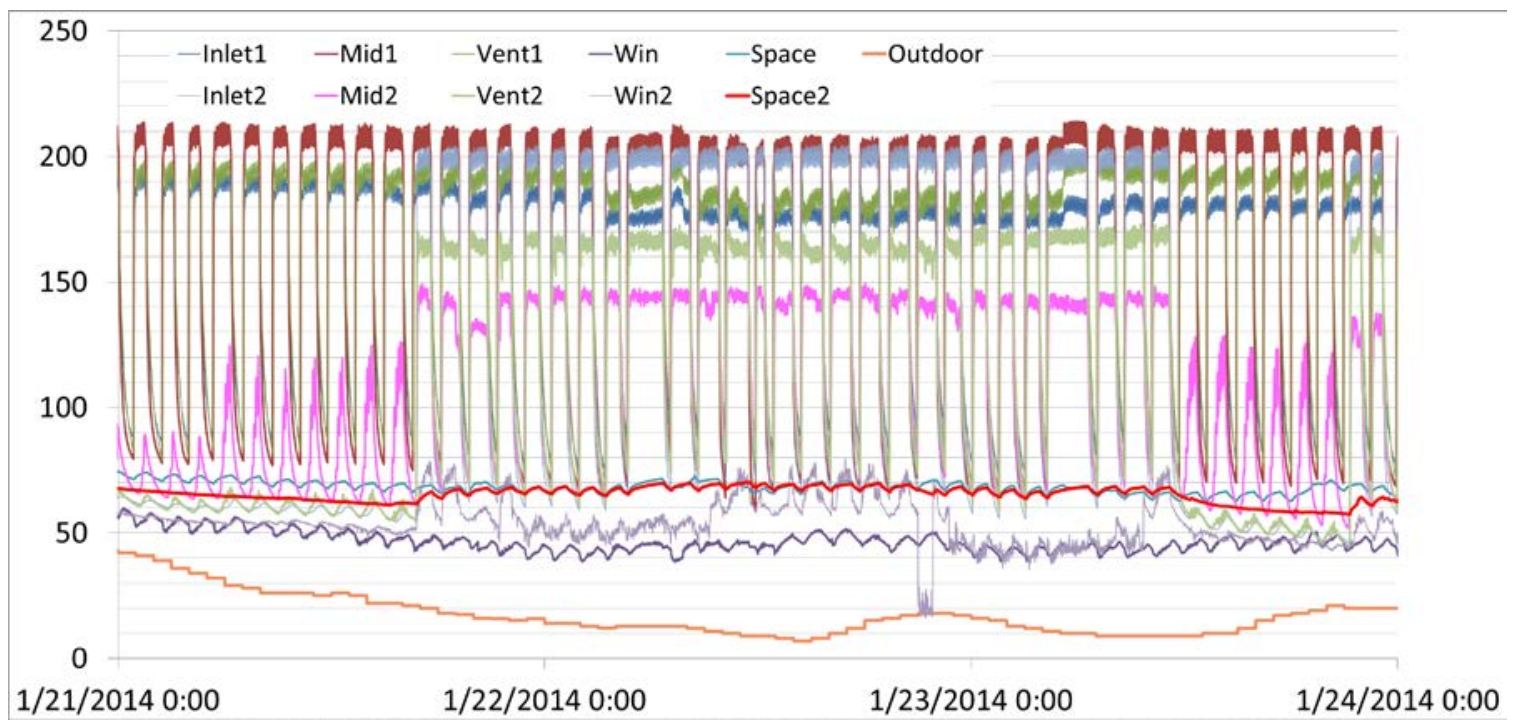

Figure 6. Radiator temperatures indicating uneven heat distribution between small and master bedrooms in apartment $1 \mathrm{~F}$

Window opening was fairly simple to observe graphically, but somewhat difficult to quantify. The two graphs in Figure 7 show that window opening events (circled in green) appear as sudden drops in near-window temperature, sometimes accompanied by a more erratic trend line. Also, the near-window temperature was in some cases governed more by the radiator temperatures, and in other cases tracked fairly well with the outdoor temperature. A reasonable threshold for the near-window temperature below which windows were considered to be open was $55^{\circ} \mathrm{F}$ (except for apartment 1F's living room window before the TRV installation; because of cooler average window temperatures $45^{\circ} \mathrm{F}$ was deemed a better fit). 


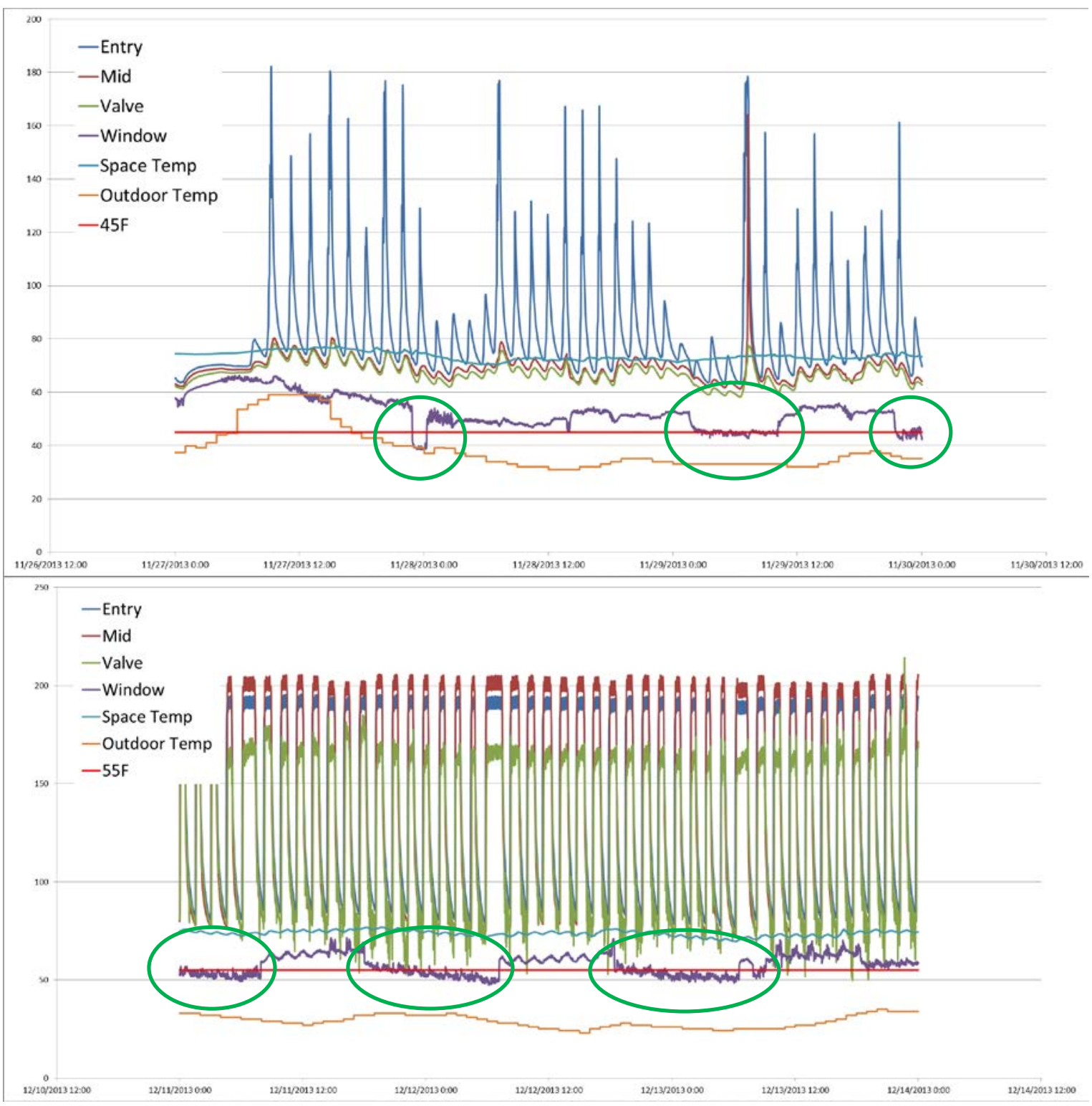

Figure 7. Window opening indicated by temperature drops, circled in green, in apartment $1 \mathrm{~F}$ living room (top) and apartment $1 \mathrm{~A}$ living room (bottom)

\subsubsection{Pre- and Post-Thermostatic Radiator Valve Installation Space Temperature Comparison}

As a measure of TRV efficacy, space temperature readings for each room in apartments $1 \mathrm{~A}$ and $1 \mathrm{~F}$ were averaged and compared before and after the TRV installation date. To isolate the influence of the TRVs on space temperature from other variables, space temperature readings that corresponded with window opening events and boiler cycle "off" time were excluded from these averages. Window opening was defined as above; radiator temperatures lower than $100^{\circ} \mathrm{F}$ were judged to represent boiler cycle "off" time. The resulting space temperature averages are given in Table 5 in Section 3. 


\subsubsection{Mild and Severe Heating Weather Space Temperature Comparison}

Recorded indoor space temperatures for each of the eight rooms were also grouped along two outdoor temperature bands: mild heating weather and severe heating weather. These bands included all times in the post-TRV installation data collection period when the outdoor temperature was $35^{\circ}-50^{\circ} \mathrm{F}$ and $10^{\circ}-25^{\circ} \mathrm{F}$, respectively. The average and standard deviation were calculated for each group and are shown in Table 6 in Section 3.

\subsection{Utility Bill Analysis for Entire Test Property}

Natural gas consumption records for the property were obtained from the utility company for a 27-month period (April 4, 2012 to July 1, 2014), capturing full heating seasons before and after TRVs were installed building-wide in the summer of 2013. Each billing period corresponded roughly to a calendar month. Because the interruptible oil billing periods are based on delivery dates and do not necessarily correspond to the usage period, oil records were not collected. To discount unknown fuel oil heating consumption from the analysis, gas billing periods with more than 10 hours of $<20^{\circ} \mathrm{F}$ outdoor air temperature (the fuel switchover temperature for this property) were removed from the analysis discussed below.

Daily base load usage was estimated as the average daily use of the main gas account during non-heating season billing periods (June 1 to September 31). This approach neglects the influence of seasonal variations on cold water inlet temperature and occupant behavior, which may be significant. Average heating therms/day were calculated for each heating season (October 1 to May 31) billing period by subtracting estimated daily baseload usage from each bill. Monthly billing period average temperatures were calculated from LaGuardia airport weather station records. The graph in Figure 8 shows average heating therms/day plotted against average monthly temperature for the heating seasons before (in orange; includes 2 months from the 2011-2012 heating season as well) and after (in blue) the building-wide TRV installation. Linear regression lines for the pre- and post-building-wide TRV installation data points are also shown in the graph.

\subsection{Building Energy Optimization Program Conceptual Payback Model}

Energy savings from reduced average indoor space temperature were estimated using Building Energy Optimization Program (BEopt ${ }^{\mathrm{TM}}$ ) software. The indoor space heating set point for a typical two-bedroom apartment with three radiators and a single exterior, uninsulated masonry wall was varied from $80^{\circ} \mathrm{F}$ down to $71^{\circ} \mathrm{F}$ (the baseline condition consistent with the Building America benchmark) to determine the reduction in annual natural gas heating therms per degree of reduced space temperature. The present dollar value of the therms saved over the useful life of the TRVs was compared against their installed cost to determine the minimum level of overheating that would allow TRVs to have a positive payback. Modeling assumptions are given in Table 10 in the Appendix, and the financial calculation assumptions are given below in Table 4. 


\section{Results}

Table 4. Cost-Benefit Financial Assumptions

\begin{tabular}{c|c}
\hline Installed Cost of Three TRVs & $\$ 420$ \\
\hline Useful Life & 15 years \\
Discount Rate & $3 \%$ \\
\hline Cost per Natural Gas Therm & $\$ 1.10$ \\
\hline
\end{tabular}

\subsection{Effect of Thermostatic Radiator Valves on Indoor Space Temperature}

The pre- and post-TRV installation space temperature averages given in Table 5 show a reduction of $2^{\circ} \mathrm{F}$ for apartment $1 \mathrm{~A}$ (in which the new TRVs were installed) and an increase of $1^{\circ} \mathrm{F}$ for apartment $1 \mathrm{~F}$ (in which the old TRVs were installed). Three rooms in the study experienced a reduction in space temperature, three had no change, and in two rooms the average recorded space temperature increased.

Table 5. Average Pre- and Post-TRV Space Temperatures

\begin{tabular}{|c|c|c|c|c|c|}
\hline \multicolumn{3}{|c|}{ Apartment 1A-New TRVs } & \multicolumn{3}{|c|}{ Apartment 1F-Old TRVs } \\
\hline Room & Pre & Post & Room & Pre & Post \\
\hline Kitchen & 79 & 77 & Kitchen & 75 & 77 \\
\hline Small Bedroom & 73 & 70 & Small Bedroom & 71 & 71 \\
\hline Living Room & 76 & 76 & Living Room & $73 *$ & 75 \\
\hline Master Bedroom & 77 & 74 & Master Bedroom & 71 & 71 \\
\hline Average & 76 & 74 & Average & 73 & 74 \\
\hline
\end{tabular}

\subsection{Thermostatic Radiator Valve Performance in Mild and Severe Heating Weather}

This analysis was intended to measure TRV performance during varying weather conditions, but the space temperature averages and standard deviations given below (Table 6) appear to illustrate other aspects of the building's heating system. From mild to severe cold weather, both apartment averages show a $3^{\circ} \mathrm{F}$ reduction in space temperature, likely indicating that the slope of the boiler outdoor reset control does not match the rate of change in heat loss experienced by the building from mild to severe cold. The average standard deviation for apartment $1 \mathrm{~A}$ is $2.6^{\circ} \mathrm{F}$ in both mild and severe weather, while it ranges from $3.5^{\circ} \mathrm{F}$ to $3.6^{\circ} \mathrm{F}$ for apartment $1 \mathrm{~F}$. Because the space temperature swings are nearly constant from mild to severe cold outdoor conditions but vary between the two apartments, this may be caused by a tendency for the residents in apartment $1 \mathrm{~F}$ to open their windows more often. 
Table 6. Mild and Severe Heating Weather Space Temperatures ( $\left.{ }^{\circ} \mathrm{F}\right)$

\begin{tabular}{c|c|c|c|c}
\hline \multirow{2}{*}{ Room } & \multicolumn{4}{|c}{ Apartment 1A } \\
Kitchen & $\begin{array}{c}\text { Space } \\
\text { Temperature }\end{array}$ & $\begin{array}{c}\text { Mild } \\
\text { Standard } \\
\text { Deviation }\end{array}$ & $\begin{array}{c}\text { Severe Weather } \\
\text { Space } \\
\text { Temperature }\end{array}$ & $\begin{array}{c}\text { Severe } \\
\text { Standard } \\
\text { Deviation }\end{array}$ \\
\hline Small Bedroom & 76 & 2.9 & 76 & 2.9 \\
\hline Living Room & 71 & 2.9 & 67 & 2.7 \\
\hline Master Bedroom & 76 & 2.2 & 73 & 2.3 \\
\hline Average & 75 & 2.3 & 73 & 2.4 \\
\hline \multirow{2}{*}{ Room } & & $\mathbf{2 . 6}$ & 72 & $\mathbf{2 . 6}$ \\
\hline Kitchen & Space & Standard & Space & Standard \\
\hline Small Bedroom & 76 & 4.6 & 73 & Severe \\
\hline Living Room & 71 & 3.2 & 68 & 3.7 \\
\hline Master Bedroom & 75 & 2.5 & 72 & 2.6 \\
\hline Average & 72 & 3.8 & 70 & 3.7 \\
\hline
\end{tabular}

\subsection{Effect of the Building-Wide Thermostatic Radiator Valve Installation on Space Heating Energy Use}

Analysis of natural gas consumption for the winter seasons before and after the building-wide TRV installation shows that the number of heating therms used per day, normalized by average outdoor air temperature, stayed nearly constant (Figure 8). Possible reasons for the lack of heating energy savings are given in Section 4. 


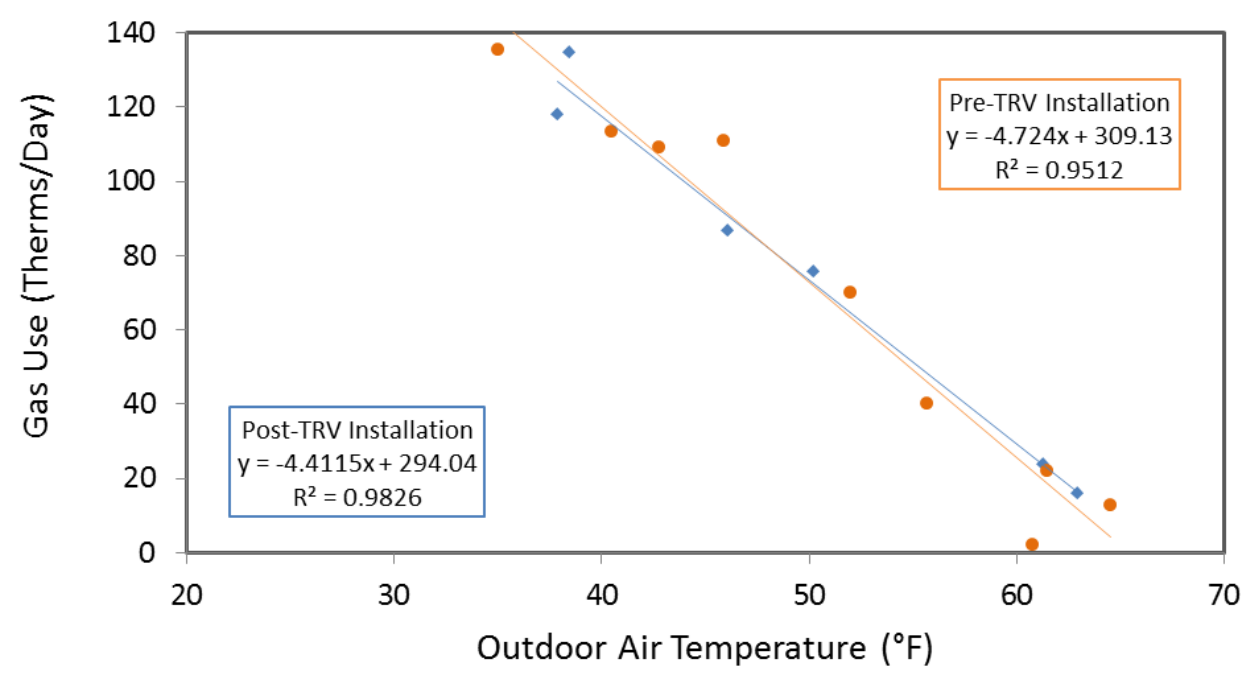

Figure 8. Heating fuel usage versus average outdoor temperature before and after building-wide TRV installation

\subsection{Cost-Benefit Conceptual Model Results}

A median cost of $\$ 140$ per installed one-pipe TRV was obtained from consultant interviews and contractor quotes for materials and labor, making the total cost of three TRVs in the modeled apartment unit $\$ 420$. Using $71^{\circ} \mathrm{F}$ as the post-retrofit target space temperature, annual heating therms saved, and the present value of the dollar savings over the useful lifetime of the TRVs for pre-retrofit overheating conditions are shown in Table 7. Following these modeled savings projections, the installation of TRVs would have a positive payback in cases where the existing space temperature exceeds $76^{\circ} \mathrm{F}$ and the post-retrofit target temperature of $71^{\circ} \mathrm{F}$ is achieved.

Table 7. Present Value of Fuel Savings over Life of TRV

\begin{tabular}{c|c|c}
\hline $\begin{array}{c}\text { Pre-TRV } \\
\text { Temperature }\end{array}$ & $\begin{array}{c}\text { Annual } \\
\text { Therms } \\
\text { Saved }\end{array}$ & $\begin{array}{c}\text { Present Value } \\
\text { of Fuel } \\
\text { Savings }\end{array}$ \\
\hline $\mathbf{7 1}^{\circ} \mathbf{F}$ & - & - \\
\hline $\mathbf{7 2}^{\circ} \mathbf{F}$ & 4 & $\$ 53$ \\
\hline $\mathbf{7 3}^{\circ} \mathbf{F}$ & 8 & $\$ 105$ \\
\hline $7^{\circ} \mathbf{F}$ & 15 & $\$ 197$ \\
\hline $7^{\circ} \mathbf{F}$ & 23 & $\$ 302$ \\
$\mathbf{7 6}^{\circ} \mathbf{F}$ & 31 & $\$ 407$ \\
\hline $7^{\circ} \mathbf{F}$ & 38 & $\$ 499$ \\
\hline $7^{\circ} \mathbf{F}$ & 44 & $\$ 578$ \\
\hline $7^{\circ} \mathbf{F}$ & 50 & $\$ 657$ \\
\hline $\mathbf{8 0}^{\circ} \mathbf{F}$ & 55 & $\$ 722$ \\
\hline
\end{tabular}




\subsection{Resident and Superintendent Interviews}

The residents of apartments $1 \mathrm{~A}$ and $1 \mathrm{~F}$ were given an initial brief survey to gain some insight into their prior behavior and attitudes with regard to the building's heating system. Both parties had lived in the building for 5 or more years and despite experiencing some discomfort related to both over- and underheating, neither had brought the problem to the attention of the building superintendent. The elderly couple in 1A commented that their overall thermal comfort was good; the family living in apartment $1 \mathrm{~F}$ reported that while the apartment was comfortable in mildly cold weather, during severe cold the bedrooms became too cold. Both groups stated that they opened windows to mitigate overheating.

An informal follow-up with these same residents revealed that they perceived the TRVs positively. However, the residents in apartment $1 \mathrm{~F}$ still reported underheated bedrooms, and the data collected show that the windows were still being opened regularly in both apartments during the heating season even after the TRVs were installed.

The building superintendent also conveyed his opinion that the TRVs had positively affected comfort in the winter following the building-wide installation. 


\section{Discussion}

The results of the analysis at the apartment and building levels do not suggest that TRVs significantly reduced average space temperature and heating fuel consumption. However, it would not be reasonable to conclude from the data collected that TRVs do not effectively control space temperatures. Several critical cofactors that appear to drive space heating levels and fuel use at the test site were identified: the building's heating system equipment, condition and operating parameters, and resident behavior. General considerations regarding TRVs also are discussed in Section 4.1.

\subsection{Influence of Steam System Configuration on Thermostatic Radiator Valve Performance}

\subsubsection{Air Venting Imbalance}

The radiator temperature data exhibited signs of uneven steam distribution between radiators, likely caused by uneven or inadequate venting on the steam mains and risers, and air vent failure at the radiator. Consistent steam was not entering at least one of the eight radiators monitored before the TRVs were installed (Figure 5), and even after the installation, the data show that steam was not arriving as quickly to some radiators as it was to others (Figure 6). This is a common problem with one-pipe steam systems (Choi, Ludwig, \& Brand, 2012). If this is indeed a building-wide issue at the test site, TRVs installed in underheated rooms would not be expected to limit or lower the average space temperature.

\subsubsection{One-Pipe Convector Radiator Considerations}

There are several key differences between the application of TRVs in a one-pipe convector radiator system versus those with two-pipe systems and/or cast-iron radiators. With two-pipe steam, the TRV can be placed at the radiator inlet where it can block steam entirely from entering the radiator when the TRV is closed. In a one-pipe steam application, TRVs are installed at the vent side of the radiator, principally because of debris and condensate clogging issues at the inlet. A one-pipe TRV in this position can work in either of two ways:

- If the space temperature has already satisfied the sensor and the TRV is closed before a steam cycle begins, it can prevent the entire mass of air in the radiator from exiting the radiator body. The cycle runs and no heat is added to the space (with one caveat that will be discussed in Section 4.1.3).

- If the TRV is open at the beginning of a steam cycle and closes when the air has been only partly displaced from the radiator body, it will effectively limit the volume of radiator body that can receive steam during the remaining steam cycle.

The second scenario requires that once a steam cycle begins, the TRV sensor is able to actuate the valve in a shorter time span than that in which the air is displaced from the radiator. A large cast-iron radiator can take 8-10 minutes to fill completely with steam, whereas convectors will fill in 2 minutes or less, as shown by the data collected for the test apartments. The reaction of the TRV has to happen, therefore, in less than 10 minutes from the beginning of the steam cycle for cast iron and in less than 2 minutes for convectors. The sensor material begins to expand immediately upon a change in sensor temperature (Boss, 2014); therefore, the limiting factor is more likely to be the time required to establish a convection current within the room that bathes 
the TRV sensor in air that exceeds its set point temperature. The location in which the TRV sensor is placed within the room is then a critical factor in responding to the higher temperatures in the convective current. Also, the TRV temperature set point may, relative to the desired space temperature, impact this response time.

Precise data showing that room convection current establishment times allow TRVs to function in this regard with relatively fast-filling convector radiators were not collected as part of this study, but could be useful in providing guidance on TRV installations, particularly sensor placement.

\subsubsection{Boiler Control Set Points}

Boiler operating pressure and outdoor reset curve settings could affect both the ability of TRVs to control individual radiator heat output and the building-wide effect of TRVs on heating fuel usage. Although the TRV manufacturer's recommended limit for operating steam pressure was 2 psi above atmospheric pressure, the steam boiler in this study was set to operate at a range of 2-5 psi. Neglecting for pressure drops along the steam mains and risers, 5 psi at a radiator would compress the trapped air volume by approximately $25 \%$ and, therefore, allow that radiator to emit $25 \%$ of its maximum heat output, even when the TRV has successfully closed. If the operating pressure could be reduced to a maximum of 2 psi, this would allow only $12 \%$ of the radiator to fill with steam in the same case, increasing the ability of the TRV to limit radiator heat output.

Pressure and volume of a gas in a vessel share the relationship:

$$
V_{\text {new }}=V_{\text {old }} \times P_{\text {old }} \div P_{\text {new }}
$$

In the case of 5 psi of steam pressure at the radiator, this would compress the trapped radiator air to a percentage of its original volume:

$$
1 \times 14.7 \div(14.7+5)=75 \%
$$

In the case of 2 psi of steam pressure at the radiator, this would compress the trapped radiator air to:

$$
1 \times 14.7 \div(14.7+2)=88 \%
$$

The TRVs used in this study were built to withstand up to 15 psi without risk of mechanical failure. (This refers to the close-off pressure of the valve. Of course, 15 psi as an operating range for the steam system would be grossly inappropriate for the reasons discussed above.)

The outdoor temperature boiler reset curve set point of "I" was maintained throughout the preand post-TRV installation analysis periods. This may be desirable and necessary - even with TRVs installed on a well-balanced and properly maintained steam heating system - to allow longer radiator output times for spaces that experience higher rates of heat loss while the building as a whole is satisfied sooner, allowing the boiler to shut down earlier in most cycles and save energy. Conversely, if the collective action of the TRVs causes the boiler to short cycle at the original setting, the reset curve set point may need to be reduced and the resulting reduction in "cycle-on" time would be expected to reduce fuel consumption. Unfortunately, 
boiler runtime and potential short-cycling cannot be inferred from the radiator temperature data that were collected in this study, because steam distribution systems are designed to maintain steam pressure for some time after the burner turns off.

Lastly, the manufacturer's operation instructions for the outdoor temperature reset boiler control indicate that the control should be set for 30-minute cycles with convector radiators, as opposed to 60- or 90-minute cycles for cast-iron radiators; however, the control at the test site was set for 60 -minute cycles for the duration of the study. Because convector radiators have significantly less mass than cast-iron radiators, they do not store thermal energy, and continue to release that energy into the conditioned space once a boiler cycle is complete, in the same manner as castiron radiators. Shorter, more frequent boiler cycles are recommended for use with convectors for this reason. The longer steam cycles in use at the test site may increase the daily temperature swing within the apartments and decrease the frequency with which the TRVs can close off a partially filled radiator at the beginning of a steam cycle.

\subsection{Existing Level and Character of Overheating}

The space temperature data collected from the two test apartments do not show extreme overheating before the TRVs were installed in those two apartments. The average pre-TRV installation space temperatures were $76^{\circ} \mathrm{F}$ and $73^{\circ} \mathrm{F}$, respectively, in apartments $1 \mathrm{~A}$ and $1 \mathrm{~F}$. If these temperatures are representative of the whole-building average, this would reduce (but not eliminate) the potential for the TRV retrofit to reduce building-wide space heating demand compared to buildings where the space heating average temperature is $80^{\circ} \mathrm{F}$ or higher.

Further, the pre-TRV installation difference of $3^{\circ} \mathrm{F}$ average space temperature between the two apartments is slight. If the variation in average temperature throughout the building is similarly small, this would also present less opportunity for TRVs to reduce overheating compared to a building in which heating demand varies greatly from apartment to apartment. For example, in a building where some apartments have large south-facing windows (high solar loads), a building with a wing exposed to high wind-wash, or one in which the residents' thermal comfort levels vary greatly, the superintendent is typically forced to maintain a high average space temperature to satisfy the coldest apartments. TRVs could reduce this need by limiting heat emitter output in rooms with less heat demand while the boiler output continues to satisfy rooms with greater heat demand. With this consideration in mind, it is worth noting that the two test apartments both had predominantly northern exposure; this may have legitimately increased the demand in those apartments relative to other parts of the building where the TRVs may have more effect.

\subsection{Resident Behavior and Perception}

Although difficult to quantify, frequent window opening by the residents in apartments $1 \mathrm{~F}$ and 1A was apparent from the collected temperature data both before and after the TRVs were installed. Depending on the frequency and degree to which window opening occurs, a given TRV sensor might never exceed its set point temperature and therefore, never close to limit radiator output.

Some of the positive perception of the TRVs relayed by the residents and superintendent, aside from potential psychological value, may be due to a real improvement in thermal comfort caused by higher heat output post-TRV in the case of the room radiator vent that was obstructed and not receiving steam before the TRV installation. 


\subsection{Ventilation System}

Prewar buildings such as the one in this study are typically not served by a central mechanical ventilation system to bring fresh air into the living spaces and exhaust stale air and odors from the kitchens and bathrooms. Rather, operable windows controlled by building residents are the principal means of ventilation. This is a case where the design of the building is intrinsically sensitive to tenant behavior; cooking habits and individual preferences are expected to vary the ventilation levels. Window ventilation is a separate phenomenon from window-mediated space temperature control, but may also contribute to improper TRV function.

\subsection{Thermostatic Radiator Valve Considerations}

The experiment and analysis are subject to the following potential uncertainties:

- Variety of TRV makes and models. TRVs are manufactured by a number of companies, each with multiple models that are subject to design modifications over time. In addition, there are two main types of TRV operation: wax and bellows types. Bellows types can be either liquid or vapor filled. Under this plan, only one old TRV model and one new model were tested, potentially limiting the applicability of the results. Because TRVs with vapor-filled bellows are commonly available and reportedly the most accurate (Boss, 2014), these were used for both the old and new TRVs in this study.

- TRV adjustments. Despite requests not to do so, residents may adjust the knob on the adjustable TRVs in an effort to control heat over the course of the study monitoring period, potentially affecting the results. Only the TRVs in the two temperature-monitored apartments in this study were locked to prevent adjustment after installation. The remaining TRVs were not locked, but the thermostatic operators were located within convector enclosures, making tampering unlikely.

- Radiator inlet valve seals and other connections. TRVs, as well as radiator air vents, function on the premise that they can control the movement of air within a radiator. To the extent that any leaks occur at threaded connections within the radiator assembly or at the inlet valve seal, this function may be compromised and/or steam may escape directly into the conditioned space.

- TRV sensor placement. The TRVs installed in most of the apartments (except the two monitored apartments) were installed with their temperature sensors outside of the convector cabinets where they were not in the direct return air stream to the convector. If these wall-mounted TRV sensors experienced lower temperatures as a result of their location, more heat may have been delivered to the spaces than would have been the case if the sensors were installed beneath the convectors; the opposite is also possible. This may have affected the utility bill analysis. Infiltration by unconditioned air (drafts) through small gaps in window frames and radiator cabinet framing could also cause a nearby TRV sensor to read low temperatures that do not reflect the average ambient temperature.

\subsection{Cost-Benefit Analysis}

During interviews conducted as part of this test plan development, a wide range of costs were cited by industry members, varying by nearly a factor of three. These represent real costs with variation attributable in part to the product used and in part to the installation method employed 
(i.e., do-it-yourself or by licensed contractors). As a result, in some circumstances, TRVs can be cost effective, while in others they are not affordable for whole-building solutions and possibly suitable only for specific problem (i.e., overheated) areas. The threshold of a minimum $77^{\circ} \mathrm{F}$ overheating in order for TRVs to have a positive payback is higher than that found in the McNamara (1995) study $\left(75^{\circ} \mathrm{F}\right)$. However, this is explained by the much slower rise in the cost of natural gas compared to that of TRV installation (in the McNamara study, the total installed cost was $\$ 50$ per TRV, and natural gas was $\$ 0.70 /$ therm).

\subsection{Impacts and Tradeoffs}

Several factors should be considered in the deployment of TRVs (see Table 8).

Table 8. TRV Impacts and Tradeoffs

\begin{tabular}{c|c}
\hline System & Impact and Tradeoff, If Any \\
\hline $\begin{array}{c}\text { Occupant Comfort } \\
\text { TRVs are intended to reduce overheating, which improves occupant } \\
\text { comfort. They also provide an improved level of occupant control } \\
\text { over heating. However, slow response times and a lack of } \\
\text { understanding of how they operate have been reported to lead to } \\
\text { tenant dissatisfaction (Colgrove, 2012). }\end{array}$ \\
$\begin{array}{c}\text { Occupant Health and } \\
\text { Safety }\end{array}$ & $\begin{array}{r}\text { Overheating in winter can result in excessively low humidity levels, } \\
\text { which can have negative health consequences. }\end{array}$ \\
$\begin{array}{c}\text { Equilding and } \\
\text { Durability }\end{array}$ & $\begin{array}{r}\text { Reducing overheating should decrease energy use, and thus the load } \\
\text { on the heating system, possibly increasing the equipment's lifetime. }\end{array}$ \\
$\begin{array}{c}\text { Building Code } \\
\text { Compliance Issues }\end{array}$ & $\begin{array}{r}\text { TRVs should maintain building owners' ability to comply with } \\
\text { local minimum heat ordinances. }\end{array}$ \\
$\begin{array}{c}\text { Building and } \\
\text { Equipment } \\
\text { Maintainability }\end{array}$ & $\begin{array}{r}\text { TRVs are another component and as such must be maintained; } \\
\text { however, most interview respondents indicated that they require } \\
\text { little or no maintenance. }\end{array}$ \\
\hline
\end{tabular}




\section{Conclusions}

\subsection{Research Questions}

This research addresses the following questions:

1. What are common prevailing opinions and perceptions regarding TRVs among the building community and how does this affect their deployment?

Several of the market professionals' assertions recorded in the introduction to this study were reflected in the results of this work (see Table 9).

Table 9. TRV Comments and Findings

\begin{tabular}{c|c}
\hline Comment & Finding \\
\hline $\begin{array}{c}\text { Tenants Continue To Open Windows } \\
\text { With TRVs }\end{array}$ & $\begin{array}{c}\text { In the initial winter heating season for which data } \\
\text { were collected, the two monitored residents } \\
\text { continued to open windows regularly. }\end{array}$ \\
$\begin{array}{c}\text { Problematic Remote Temperature Sensor } \\
\text { Placement }\end{array}$ & $\begin{array}{c}\text { TRV sensors were installed contrary to the } \\
\text { manufacturer's suggestion in all but two of the } \\
\text { apartments at the test building; however, a } \\
\text { conclusive effect on space temperature has not } \\
\text { been determined. }\end{array}$ \\
$\begin{array}{c}\text { Failure To Ensure That Steam System Is } \\
\text { Properly Commissioned To Work With }\end{array}$ & $\begin{array}{c}\text { This study found some evidence of steam } \\
\text { distribution imbalance and suboptimal steam } \\
\text { pressure that would negatively affect TRV } \\
\text { performance. }\end{array}$ \\
$\begin{array}{c}\text { Apartment-Level Control Seems To } \\
\text { Provide Increased User Comfort Mainly } \\
\text { Due To Psychological Factors }\end{array}$ & $\begin{array}{c}\text { There is qualitative evidence that lends some } \\
\text { support to this idea. }\end{array}$ \\
\hline
\end{tabular}

2. How effectively do new and old TRVs control indoor temperature under various outdoor conditions?

Conclusive measures of TRV performance in varying outdoor weather conditions and measures of the efficacy of old versus new TRVs could not be obtained from the results of the test plan because of the same confounding factors mentioned below.

3. How much space heating energy can be saved through TRV installations and how cost effective are TRV retrofits in low-rise multifamily buildings? 
McNamara (1995) showed an average of 15\% reduction heating fuel consumption that was not borne out by the analysis of the initial post-TRV installation heating season's utility bills in this study. However, several possible reasons are not attributable to a lack of proper performance by the TRVs, including existing steam distribution imbalance, possible TRV sensor location issues, a persistent window-opening habit by the monitored apartments' residents, and a failure to optimize the boiler control set points (especially the upper limit of operating steam pressure) as an integral part of the TRV retrofit.

The results of the BEopt-modeled TRV savings showed that average space temperature reduction needs to be in the area of $6^{\circ} \mathrm{F}$ in order for TRVs to be cost effective. The assumptions madewall and window R-values, wall-to-window ratio, infiltration rate, ventilation rate, heating system efficiency, fuel cost per Btu, and number of radiators - should reasonably approximate an older multifamily building. However, each of these factors will vary considerably from project to project, and the modeled break-even point should be understood as an approximation that cannot be applied universally.

The lack of actual heating fuel savings witnessed in this study underscores the need, especially given the utility company and state agency financial support for TRV installations, to include whole steam system commissioning alongside or as a prerequisite to TRVs in order to maximize the effect of public incentives and private investment.

\subsection{Key Lesson: Monitor Space Temperatures and Balance Steam Distribution}

Failed air vents and uneven steam main venting are critical to address either in conjunction with or before a TRV installation. In some apartments, this is likely to increase heat supply, as happened in the test here. An increase in space temperature for underheated apartments would be a desirable result of air vent maintenance and steam vent balancing; however, this may lower expected heating fuel savings if good space temperature data have not been obtained beforehand to provide an accurate picture of existing building overheating. Once underheating has been solved, TRVs may still provide a useful upper bound to apartment space temperatures. By contrast, radiator and steam main air vents were inspected for function and proper size, and replaced as necessary in the buildings that were included in the McNamara (1995) study. Ensuring that the operating steam pressure and boiler control set points are appropriate for TRVs and the distribution equipment (convectors or cast-iron radiators) involved is also a must for onepipe steam retrofits.

Monitoring the existing space temperature spread and establishing the causes of variation before a retrofit strategy is chosen would allow the consultant and building owner to better assess the potential benefits of a whole-building TRV retrofit, selective installation of TRVs in some units, or simply balancing the steam distribution venting. If feasible, an iterative approach in which the venting and boiler controls are tuned first and TRVs are subsequently considered if overheating control opportunities remain, would be an ideal means of minimizing unnecessary costs.

\subsection{Resident Interaction}

Tenant behavior in the monitored apartments proved difficult to predict and influence. If any conclusion is to be drawn, it is that space heat imbalance was present at the test site and the stated reason for the tenants to open windows. From this, it is plausible that perhaps providing balanced steam heat and consistent space temperatures is again a prerequisite to TRV 
installation, but for the added reason of reducing the need and habit for tenants to regulate space temperatures in this way. The inherent variability in window ventilation still would remain, however. The building owners involved in the McNamara (1995) study held resident workshops prior to TRV installation to familiarize their tenants with the technology and its proper use; this may have had some influence on the more favorable outcomes of that study.

\subsection{Future Research}

Several compelling questions arose over the course of this test plan that fell outside the study scope but could potentially reveal important additional aspects of TRV function.

- The time lapse between the initiation of a steam cycle and TRV closure, and the period of time required for radiators to fill with steam, play a large role in the ability of TRVs to limit radiator heat output. These time frames are governed by convection current establishment within the space, the placement of the sensor to best intercept that current, and the volume of the radiator body/flow rate of air through the vent.

Typical convection current establishment times should be identified and sensor placement best practices defined. In conjunction with this, fill times for standard radiator types should be better quantified so that practitioners can identify whether given distribution equipment will be a "good fit" for TRVs and optimize the installation for maximum space temperature control.

- Mutual interactions between TRVs and the steam boiler affect both the ability of the TRVs to limit radiator heat output and overall boiler runtime, both of which determine fuel savings. As discussed in this test plan, the boiler steam supply pressure range could affect the volume of steam that TRVs allow to enter radiators in a one-pipe system, and this effect needs to be further quantified. The collective effect of TRV action on distribution system pressure should, in turn, have some effect on burner runtime within each steam cycle; this effect should be understood so that excessive burner short-cycling can be avoided and outdoor reset curve set points can be optimized post-TRV installation. 


\section{References}

ARIES Collaborative. (2011). Hydronic Heating Systems Expert Meeting. New York: U.S. Department of Energy.

Boss, B. (2014, July 10). (J. Dentz, Interviewer)

Choi, J., Ludwig, P., \& Brand, L. (2012). Steam Balancing and Tuning for Multifamily Residential Buildings in Chicagoland. Chicago: U.S. Department of Energy.

Colgrove, M. (2012, December 26). (J. Dentz, Interviewer)

Dentz, J., Henderson, H., \& Varshney, K. (2013). Overheating in Hot Water and Steam Heated Multifamily Buildings. New York: Advanced Residential Integrated Energy Systems Collaborative.

Gifford, H. (2003, June). How to make a two pipe steam heating system really work. www.ABMA.com, pp. 26-33.

Gifford, H. (2004, January). Choosing Thermostatic Radiator Valves. www.ABMA.com.

Jayne Choi, P. L. (2012). Steam System Balancing and Tuning for Multifamily. Partnership for Advanced Residential Retrofit.

Madnick, P. (2014, July 25). (J. Dentz, Interviewer)

McNamara, M. (1995). Thermostatic radiator valve (TRV) demonstration project. NYSERDA final report, prepared by EME group.

Metzger, C. E., \& Norton, P. (2014). The Building America Indoor Temperature and Humidity Measurement Protocol. Golden, CO: National Renewable Energy Laboratory.

National Renewable Energy Laboratory. (2012). Building America Critical Path Milestones. Golden, CO: Department of Energy.

New York City Administrative Code \$27-2029. (2014). Retrieved December 3, 2014, from Laws of New York: http://public.leginfo.state.ny.us

Peterson, G. (1985). Achieving even space heating in single pipe steam buildings, A joint research project of Minnegasco and the Minneapolis energy office.

Tahersima, F., Stoustrup, J., \& Rasmussen, H. (2011). Eliminating oscillations in TRVcontrolled hydronic radiators. 50th IEEE Conference on Decision and Control and European Control Conference. Orlando, FL.

Tahersima, F., Stoustrup, J., Rasmussen, H., \& Nielsen, P. (2010). Thermal analysis of an HVAC system with TRV controlled hydronic radiator. Automation Science and Engineering.

Trüschel, A. (2002). Hydronic heating systems: The Effect Of Design On System Sensitivity. Ph.D. Dissertation. Göteborg, Sweden: Department of Building Services Engineering, Chalmers University of Technology.

U.S. Department of Energy. (2013, November 26). Thermostats. Retrieved August 1, 2014, from Energy.gov: http://energy.gov/energysaver/articles/thermostats

Weker, P., \& Mineur, J. (1980). A performance index for thermostatic radiator valves. Applied Energy 6, (3): 203-215.

$\mathrm{Xu}, \mathrm{B} ., \mathrm{Fu}, \mathrm{L} ., \mathrm{E}$ Di, H. (2008). Dynamic simulation of space heating systems with radiators controlled by TRVs in buildings,. Energy and Buildings 40, (9): 1755-1764. 


\section{Appendix}

Table 10. BEopt Modeling Assumptions

\begin{tabular}{|c|c|c|c|}
\hline Input & Value & Input & Value \\
\hline Total Finished Floor Area & $750 \mathrm{ft}^{2}$ & Overhangs & None \\
\hline Bedrooms & 2 & Air leakage & $6 \mathrm{ACH} 50$ \\
\hline Baths & 1 & Mechanical ventilation & None \\
\hline Left Walls Attached & True & Central air conditioner & None \\
\hline Right Walls Attached & True & Furnace & None \\
\hline Back Walls Attached & True & Boiler & Gas, hot water, forced draft, $80 \%$ AFUE \\
\hline Age of Home & 90 years & Electric baseboard & None \\
\hline Orientation & $\begin{array}{c}\text { West }(8 \mathrm{ft} \times 30 \mathrm{ft} \\
\text { exterior wall })\end{array}$ & Air source heat pump & None \\
\hline Neighbors & None & Ground source heat pump & None \\
\hline Heating Set Point & $71^{\circ} \mathrm{F}$ & Ducts & None \\
\hline Cooling Set Point & $76^{\circ} \mathrm{F}$ & Ceiling fan & None \\
\hline Natural Ventilation & Benchmark & Water heater & Gas Standard \\
\hline Interior Shading & Benchmark & Distribution & Uninsulated, TrunkBranch, copper \\
\hline Wood Stud & None & Lighting & Benchmark \\
\hline Double Wood Stud & None & Refrigerator & Benchmark \\
\hline CMU & 8-in hollow & Cooking range & Benchmark \\
\hline SIP & None & Dishwasher & None \\
\hline ICF & None & Clothes washer & None \\
\hline Other & None & Clothes dryer & None \\
\hline Wall Sheathing & None & Extra refrigerator & None \\
\hline Exterior Finish & Brick, medium/dark & Freezer & None \\
\hline Unfinished Attic & $\begin{array}{l}\text { Adiabatic roof } \\
(\mathrm{R}-1500)\end{array}$ & Pool heater & None \\
\hline Roof Material & $\begin{array}{c}\text { Asphalt shingles, } \\
\text { medium }\end{array}$ & Pool pump & None \\
\hline Radiant Barrier & None & Hot tub/spa heater & None \\
\hline
\end{tabular}




\begin{tabular}{|c|c|c|c|}
\hline Input & Value & Input & Value \\
\hline Unfinished Basement & Adiabatic (R-500) & Hot tub/spa pump & None \\
\hline Interzonal Floor & R-38 fiberglass batt & Well pump & None \\
\hline Carpet & $0 \%$ carpet & Gas fireplace & None \\
\hline Floor Mass & Wood surface & Gas grill & None \\
\hline Exterior Wall Mass & 5/8-in. drywall & Gas lighting & None \\
\hline Partition Wall Mass & 5/8-in. drywall & Other electric loads & 1 \\
\hline Ceiling Mass & $\begin{array}{l}\text { Simulated concrete } \\
\text { slab }\left(15 \mathrm{Btu} /{ }^{\circ} \mathrm{F}-\mathrm{ft}^{2}\right)\end{array}$ & Other hot water loads & 1 \\
\hline Window Areas & $100 \mathrm{ft}^{2}$ & Photovoltaic system & None \\
\hline Windows & $\begin{array}{l}\text { Double-pane, clear, } \\
\text { metal, thermal } \\
\text { break, air fill }\end{array}$ & EPW location & USA_NYLaGuardia.AP.725030_TMY3 \\
\hline Eaves & None & Terrain & City \\
\hline
\end{tabular}


